Florida International University FIU Digital Commons

FIU Electronic Theses and Dissertations

University Graduate School

$11-28-2000$

\title{
Parental behaviors in child anxiety: an observational study
}

Delight Hicks Carmichael

Florida International University

DOI: $10.25148 /$ etd.FI14052578

Follow this and additional works at: https://digitalcommons.fiu.edu/etd

Part of the Psychology Commons

\section{Recommended Citation}

Carmichael, Delight Hicks, "Parental behaviors in child anxiety: an observational study" (2000). FIU Electronic Theses and Dissertations. 2048.

https://digitalcommons.fiu.edu/etd/2048

This work is brought to you for free and open access by the University Graduate School at FIU Digital Commons. It has been accepted for inclusion in FIU Electronic Theses and Dissertations by an authorized administrator of FIU Digital Commons. For more information, please contact dcc@fiu.edu. 
Dear Dr. Carmichael:

Florida International University's Digital Collections Center is offering a new service to graduate alumni: digitization of your theses and dissertations. This new service will enable your scholarship to be preserved and shared for research and educational purposes, at no cost to you, and will be made available through FIU's Electronic Theses and Dissertations on our Digital Commons website. The FIU Digital Commons is a digital repository for capturing, archiving and disseminating the research, creative and scholarly output of the Florida International University community. Our graduates' theses and dissertations are a valuable part of FIU's scholarship, and are a frequently accessed part of our digital collections.

Your 2000 dissertation titled Parental behaviors in child anxiety: an observational study is in the process of being digitized for preservation and so that it may be made available in Digital Commons. At your earliest convenience, please reply to this email providing your authorization for your dissertation to be made available online. Please be advised that FIU may make your dissertation available online if we do not hear back from you within 90 days. If at any point you wish to have your dissertation taken offline, please contact us at dcc@fiu.edu and we will be happy to do so. To accommodate needs such as publishing contracts and patents, FIU can also add a period of embargo, or alternatively provide only an excerpt of your dissertation.

If you have any questions or concerns, please do not hesitate to contact me. Thank you for your contributions to Florida International University!

Sincerely,

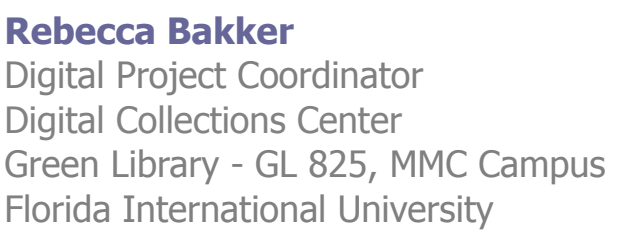

Reference \# FI14052578 